\title{
IMPLEMENTASI KEBIJAKAN PENGADAAN BERAS BADAN URUSAN LOGISTIK DALAM MEWUJUDKAN KETAHANAN PANGAN DI KABUPATEN PINRANG
}

\author{
Ummi Kalsum $^{1}$, Muhammadiah ${ }^{2}$, Anwar Parawangi ${ }^{3}$ \\ ${ }^{1,2,3}$ Program Studi Ilmu Administrasi Negara Fisip Unismuh Makassar \\ umi71720@gmail.com
}

\begin{abstract}
The purpose of this study was to find out how the implementation of the rice procurement policy of the Logistics Affairs Agency in realizing food security in Pinrang Regency. The research method used qualitative. The number of informants was 11 people. The results showed that one form of implementation of the Rice Procurement Policy of the Logistics Affairs Agency in Realizing Food Security in Pinrang Regency, namely; 1) Communication, communication realitions between Perum BULOG of Pinrang Sub-Branch with other agencies had been going well, including with partners, namely rice mill enterpreneurs who always coordinated and communicated directly with BULOG regarding rice prices. 2) Resources, in this case the resources were still inadequate, including human resources, and other resources, namely the lack of machine tools that could produce premium rice. 3) Disposition, the ability of Perum BULOG Pinrang Sub-Branch had not been maximized in controlling and coordinating BULOG rice procurement activities, so Perum BULOG conducted special education and training to improve technical and managerial skills in rice procurement. 4) Bureaucratic Structure, Perum BULOG Pinrang Sub-Branch in carrying out rice procurement policies in accordance with the main duties and functions of each sector related to the policy.
\end{abstract}

Keywords: Policy Implementation, Rice Procurement, Food Security

\begin{abstract}
Abstrak
Tujuan dari penelitian ini dilakukan untuk mengetahui bagaimana Implementasi Kebijakan Pengadaan Beras Badan Urusan Logistik Dalam Mewujudkan Ketahanan Pangan Di Kabupaten Pinrang. Metode penelitian yang digunakan adalah kualitatif. Jumlah informan 11 orang. Hasil penelitian menunjukkan bahwa salah satu bentuk implementasi kebijakan Pengadaan Beras Badan Urusan Logistik dalam Mewujudkan Ketahanan Pangan Di Kabupaten Pinrang yaitu; 1) Komunikasi, hubungan komunikasi Perum BULOG Cabang Pembantu Pinrang dengan instansi lain sudah berjalan dengan baik, termasuk dengan mitra kerja yaitu pengusaha kilang padi yang selalu berkoordinasi dan berkomunikasi langsung kepada BULOG terkait harga beras. 2) Sumber Daya, dalam hal ini sumber daya masih kurang memadai termasuk sumber daya manusia, dan sumber daya lainnya yaitu fasilitas masih kurangnya alat-alat mesin yang bisa menghasilkan beras premium. 3) Disposisi, kemampuan Perum BULOG Cabang Pembantu Pinrang belum maksimal dalam mengotrol dan mengkoordiasi kegiataan pengadaan beras BULOG, sehingga Perum BULOG melakukan pendidikan dan pelatihan khusus untuk meningkatkan keterampilan teknis dan manajerial dalam pengadaan beras. 4) Struktur Birokrasi, Perum BULOG Cabang Pembantu Pinrang dalam menjalankan kebijakan pengadaan beras sesuai dengan tupoksi masing-masing bidang terkait kebijakan tersebut.
\end{abstract}

Kata kunci : Implementasi Kebijakan, Pengadaan Beras, Ketahanan Pangan

\section{PENDAHULUAN}

Implementasi kebijakan merupakan salah satu bagian dalam proses kebijakan. Baik Edwar III (1980) maupun Anderson (1978) keduanya sepakat dalam memberikan pengertian bahwa implementasi kebijakan publik adalah suatu proses kegiatan adminisratif yang dilaksanakan setelah kebijakan ditetapkan dan disetujui (Tachjan, 2006). Menurut Edwar III (Jeane Elisabeth Langkai 2020:50) mengatakan bahwa suatu implementasi kebijakan dapat berjalan dengan baik dan efektif, maka harus memperhatikan 4 faktor dalam model implementasi antara lain yaitu: 1) komunikasi, 2) sumber daya, 3) 
disposisi, 4) struktur birokrasi. Implementasi kebijakan merupakan tahap yang paling penting dalam proses kebijakan publik. Suatu program atau kebijakan harus diimplementasikan agar mempunyai tujuan yang diinginkan. Suharto (2008) dan juga Nugroho (2014) keduanya memberikan pernyataan bahwa suatu kebijakan tidak akan berarti apabila tidak diimplementasikan, sebagus dan sebaik apapun formulasi suatu kebijakan publik, apabila dalam implementasinya tidak dilaksanakan dengan maksimal, maka formulasi kebijakan tersebut hanya menjadi sebuah wacana tanpa arti.

Daniel A. Mazmanian Dan Paul Sabatier (dalam Solihin Abdul Wahab, 1997:68) menyatakan bahwa implementasi kebijakan merupakan sebagai pelaksana keputusan kebijakan dasar, yang biasanya berbentuk undang-undang, tetapi juga berbentuk perintah-perintah atau keputusan badan eksekutif atau keputusan badan peradilan. Sedangkan menurut Wahab (Jeane Elisaberh Langkai 2020:45) dalam pandangan Denhard dan Denhard menyatakan bahwa implementasi merupakan tahap tindakan atau aksi dimana semua perencanaan dirumuskan menjadi suatu kebijakan yang dapat dioperasikan. Dan menurut Taufan L.A 2013 menyatakan bahwa implementasi adalah merupakan kegiatan atau usaha yang dilakukan oleh pelaksana kebijakan sehingga dapat memperoleh suatu hasil yang sesuai dengan tujuan atau sasaran dari kebijakan itu sendiri.

Ketahanan Pangan tidak lepas dari Undang-Undang No. 18 tahun 2012 tentang Ketahanan Pangan, yang disebutkan dalam undang-undang tersebut bahwa ketahanan pangan adalah suatu kondisi terpenuhinya pangan bagi negara sampai dengan perseorangan, yang terdiri atas tersedianya pangan yang cukup, baik jumlah maupun mutunya, merata, aman, beragam, bergizi dan terjangkau serta tidak bertentangan dengan keyakinan, agama, dan budaya masyarakat, agar dapat hidup sehat, aktif dan produktif secara berkelanjutan. Pokok-pokok pemikiran dalam Undang-Undang Nomor 18 Tahun 2012 tentang Ketahanan Pangan yaitu Pemerintah wajib mengelola stabilitas pasokan dan harga pangan pokok agar terpenuhinya kebutuhan pangan masyarakat, Pemerintah mengelola cadangan pokok, Pemerintah wajib mengeola distribusi pangan pokok dari daerah produsen ke daerah konsumen dan Pemerintah mewujudkan pangan yang bergizi bagi masyarakat.

Sesuai dengan amanat Inpres No. 5 Tahun 2015 tentang kebijakan pengadaan gabah/beras dan penyalauran beras oleh pemerintah yang merupakan pengejawantahan intervensi pemerintah dalam perberasan nasional untuk memperkuat ketahanan pangan. Secara garis besar dalam inpres tersebut disebutkan bahwa dalam melaksanakan kebijakan pengadaan gabah/beras melalui pembelian gabah/beras dalam negeri dengan ketentuan HPP (Harga Pembelian Pemerintah) yang sudah ditetapkan dan kemudian ditetapkan kebijakaan untuk menjaga stabilitas harga beras dalam negeri.

Dalam pengadaan beras, ada beberapa masalah yang ditimbulkan dalam proses implementasi kebijakan pengadaan beras saat ini. Adanya pengusaha kilang padi yang tidak berkenan menjual berasnya kepada BULOG karena harga pembelian lebih murah dari pada harga pasaran. Jadi sebagian dari para pengusaha kilang padi lebih memilih menjual berasnya kepada pedagang pengecer atau ke dearah lain. Sehingga apabila BULOG tidak membeli beras dari pengusaha kilang padi maka gudang tempat penyimpanan beras akan kosong dan tidak mempunyai stok beras.

Dengan terjadinya kekosongan gudang maka akan menyebabkan terkendalanya penyaluran bansos rastra. Dengan demikian BULOG harus menunggu kiriman beras dari daerah lain yang mempunyai surpus beras seperti Jawa Tengah, Jawa Barat, dan Jawa Timur. Meskipun masyarakat setempat tetap menerima bansos rastra dari BULOG dengan keterlambatan waktu penyaluran. Hal ini mengakibatkan BULOG Cabang Pembantu Pinrang belum bisa dikatakan berhasil dalam penerimaan hasil pengadaan beras setempat. Dengan melihat hal tersebut bahwa pengadaan beras sangat berpengaruh terhadap ketahanan persediaan untuk memenuhi kebutuhan penyaluran beras raskin, bencana alam, dan operasi pasar untuk stabilisasi harga.

Dan salah satu yang menjadi faktor penghambat proses implementasi kebijakan tersebut adalah kinerja sumber daya dalam perusahaaan ini belum makasimal yaitu terbatasnya jumlah pegawai. Sehingga 
membutuhkan manajerial yang baik, dengan hal ini, sumber daya manusia dalam pelaksanaan kebijakan pengadaan beras BULOG di Kabupaten Pinrang kurang memadai.

Namun yang menjadi permasalahan adalah masih terjadi penyaluran bansos yang tidak optimal meresahkan masyarakat kecil, penetapan HPP yang masih rendah belum mensejahterahkan petani, dan kebijakan impor pangan starategis berlawanan dengan cita-cita kemandirian pangan. selain itu lembaga stabilisasi harga saat ini masih bertumpu pada BULOG yang juga dituntut untuk menghasilkan laba, sehingga distribusi beras sebagai makanan pokok rakyat Indonesia sampai saat ini belum optimal.

Implementasi kebijakan merupakan cara agar kebijakan dapat mencapai tujuannya. Untuk dapat mengimplementasikan kebijakan publik terdapat dua cara yang berbeda yakni, langsung mengimplementasikan dengan program atau melalui intruksi dalam suatu tindakan, pelimpahan wewenang, distribusi kewenangan dan sebagainya. Dalam perumusan suatu kebijakan publik terdapat beberapa tahapan yaitu, tahap perumusan, tahap pengimplementasian, dan tahap evaluasi. Implementasi kebijakan publik merupakan pelaksanaan dari suatu kebijakan yang telah diputuskan melalui perumusan dalam kebijakan publik. Implementasi kebijakan publik sangat penting karena kebijakan yang sudah dirumuskan oleh pemerintah akan kelihatan maknanya apabila di implementasikan sebagaimana dengan tujuan dan sasaran yang diinginkan.

Menurut Wahab (Jeane Elisaberh Langkai 2020:45) dalam pandangan Denhard dan Denhard, mengatakan bahwa implementasi merupakan tahap tindakan atau aksi yang dimana semua perencanaan dirumuskan menjadi suatu kebijakan yang akan dioperasionalkan. Selain itu beliau juga mengatakan bahwa implementasikan kebijakan sebagai suatu pelaksanaan keputusan kebijakan dasar, dan biasanya dalam bentuk undang-undang, akan tetapi dalam bentuk perintah atau keputusan eksekutif yang penting atau keputusan badan peradilan. Sedangkan menurut Dunn (Nuryanti Mustari 2015:136) mengatakan bahwa implementasi kebijakan lebih bersifat pada kegiatan praktis, yang dimana didalamnya mengeksekusi dan mengarahkan.

Hal senada dikemukakan oleh Salusu (dalam Nuryanti Mustari 2015:139) yang mengatakan bahwa implementasi merupakan seperangkat kegiatan yang akan dilakukan untuk menyusun suatu keputusan. Keputusan yang dimaksud adalah untuk mencapai sasaran guna untuk merealisasikan dalam pencapaian sasaran tersebut maka diperlukan serangkaian aktifitas. Sedangkan Santoso (2009:43) dalam (Jeane Elisaberh Langkai 2020:46) mengatakan bahwa implementasi kebijakan merupakan aktivitas-aktivitas yang akan dilakukan untuk melaksanakan suatu kebijakan secara efektif. Dimana implementasi yang dimaksud disini ialah penekanannya pada mengoperasionalkan secara tepat dari tujuan kebijakan yang telah ditetapkan dalam bentuk tindakan-tindakan sementara. Sedangkan menurut Nugroho (2011:618) dalam (Jeane Elisaberh Langkai 2020:46) mengemukakan bahwa implementasi kebijakan merupakan suatu cara agar sebuah kebijakan dapat mencapai tujuannya, dan di implementasikan dalam bentuk program atau turunan dari kebijakan publik. Kebijakan publik yang dimaksud yaitu dalam bentuk undang-undang yang memerlukan pedoman umum atau pedoman pelaksanaan.

Sementara Nugroho menyoroti bahwa dalam suatu implementasi kebijakan publik diperlukan pedoman pelaksanaan sebagai turunan dari kebijakan publik. Adapun pengertian implementasi kebijakan publik menurut Akib dan Tarigan (2010:4) yang mengatakan bahwa suatu implementasi kebijakan dapat berjalan dengan lancar, perlu dilakukan desiminasi dengan baik. Adapun yang menjadi syarat dalam pengelolaan desiminasi kebijakan ada empat yaitu: (1) Adanya respek dari anggota masyarakat terhadap otoritas pemerintah dalam menjelaskan secara moral untuk mematuhi undang-undang yang dibuat oleh pihak yang berwenang. (2) Perlu adanya kesadaran untuk menerima kebijakan, kesadaran serta kemauan untuk menerima dan melaksanakan kebijakan akan terwujud manakal kebijakan tersebut dianggap logis. (3) Adanya kepercayaan bahwa kebijakan tersebut telah dibuat secara sah. (4) Didalam suatu kebijakan awalnya dianggap kontroversial, akan tetapi dengan 
berjalannya waktu maka kebijakan tersebut dianggap sebagai sesuatu yang wajar.

Dalam hal perumusan suatu kebijakan yang baik belum tentu akan berhasil apabila tidak diawali dengan desiminasi masyarakat yang akan menjadi partisipan dalam implementasi kebijakan tersebut. Sehingga respek dari masyarakat kepada pemerintah dapat dilakukan untuk upaya menjelaskan perlunya kesadaran masyarakat mematuhi kebijakan yang merupakan aturan yang dibuat oleh pihak yang berwenang.

Menurut model Merilee S Grindle 1980 (dalam Nuryanti Mustari 2015:163), mengatakan bahwa keberhasilan dalam proses implementasi kebijakan sampai pada tercapainya hasil kebijakan tergantung pada kegiatan dalam program yang telah dirancang serta dengan adanya pembiayaan yang cukup, selain dipengaruhi dari adanya conten of polcy (isi kebijakan) serta contex of implementation (konteks implementasinya). Dalam hal ini adapun isi kebijakan yang dimaksud antara lain: Adanya kepentingan yang terpenuhi oleh kebijakan (interest affected); Adanya jenis manfaat yang dihasilkan (tipe of benefit); Adanya jenis derajat perubahan yang diinginkan (extent of change envisioned); Adanya kedudukan dalam pembuatan kebijakan (site of decition making) ; Adanya pelaksanaan dalam program (program implementators); Adanya sumber daya yang dikerahkan (resources commited)

Sedangkan konteks dalam implementasi yang dimaksud adalah: Adanya kekuasaan (power); Adanya kepentingan strategi aktor yang terlibat (interest strategies of actors involved); Adanya karakteristik dalam lembaga dan penguasa (institution and regime characteristics); Adanya kepatuhan serta daya tanggap pelaksanaan (compliance and responsiveness). Sedangkan menurut Goggin Brown, dkk 1990 dalam bukunya Implementation Theory and Practice aThird Generation, secara implecit menyarankan bahwa ada 3 hal penting yang harus ada dalam implementasi kebijakan, yaitu: (1) adanya isi pesan, (2) adanya bentuk pesan, (3) dan adanya presepsi mengenai pimpinan negara. (Nuryanti Mustari 2015:162).

Menurut model George C Edward III (1980) model implementasi ini bersifat top down, yang dipengaruhi oleh empat variabel yang saling berhubungan satu sama lain. Keempat variabel tersebut yaitu (1) Komunikasi, (2) Sumber Daya, (3) Disposisi, (4) Struktur Birokrasi.

\section{METODE}

Jenis penelitian yang digunakan oleh peneliti yaitu jenis penelitian kualitatif. Karena dengan adanya penelitian penelitian kualitatif ini akan dilakukan dalam kondisi yang alamiah dan data yang terkumpul analisisnya lebih bersifat kualitatif. Dalam penelitian kualitaif yang menjadi instrumentnya ialah orang atau peneliti itu sendiri. Untuk menjadi instrument, peneliti harus mampu memiliki bekal teori, wawasan yang luas, menganalisis, mengambil gambar, serta dapat mengkonstruksi situasi sosial yang akan diteliti menjadi lebih jelas dan bermakna. Sehingga peneliti menggunakan jenis penelitian kualitatif.

Tipe penelitian yaitu dengan menggunakan tipe penelitian pendekatan deskriptif. Pendekatan deskriftip merupakan penelitian yang dapat menggambarkan terjadinya suatu gejala atau peristiwa yang akan terjadi di dalam masyarakat.

Informan dalam penelitian ini menggunakan metode purposive sampling yaitu peneliti meyakini bahwa informan yang dipilih adalah aktor dan kelompok yang terkait langsung dengan tema penelitian. Jumlah informan dalam penelitian ini adalah 11 orang, dengan itu orang-orang yang dijadikan sebagai informan harus memiliki potensi dapat menunjang peneliti untuk mengetahui tujuan dari penelitian tersebut.

\section{HASIL DAN PEMBAHASAN}

Kabupatn Pinrang sebagai salah satu Kabupaten di Provinsi Sulawesi Selatan yang terdiri dari daerah pantai, daratan, dan pegunungan. Secara astronomis, Kabupaten Pinrang terletak antara $3^{0} 19^{\prime}$ dan $4^{0} 10^{\prime}$ Lintang Selatan dan antara $119^{\circ} 26^{\prime}$ dan $119^{\circ} 47^{\prime}$ Bujur Timur. Luas wilayah Kabupaten Pinrang seluas 1961,77 km2 atau $3,14 \%$ dari luas wilayah Provinsi Sulawesi Selatan. Kabupaten Pinrang terdiri dari 12 Kecamatan dengan 39 kelurahan dan 69 desa. Secara umum keadaan sosial budaya 
masyarakat Kabupaten Pinrang dalam proses pertumbuhan sejalan dengan dinamika pembangunan. Jumlah penduduk Kabupaten Pinrang pada tahun 2020 sebanyak 403.994,00 jiwa.

Dalam pembahasan ini penulis akan membahas data-data yang diperoleh dari lokasi penelitian yang ada dilapangan terdiri dari beberapa pernyataan informan yang dihasilkan setelah melakukan observasi, wawancara, dan dokumentasi yang akan dibahas secara berurut. Pada bagian pertama penulis akan membahas terlebih dahulu karakteristik/identitas dari informan yang terdiri dari: Kepala Perum BULOG Cabang Pembantu Pinrang, Seksi Administrasi dan Keuangan Perum BULOG Cabang Pembantu Pinrang, Sekesi Pengadaan, Pelayanan \& Analisa Pasar Perum BULOG Cabang Pembantu Pinrang, Kepala Dinas Ketahanan
Pangan Kabupaten Pinrang, Kabid Distribusi dan Cadangan Pangan Dinas Ketahanan Pangan, Pengusaha kilang padi Kabupaten Pinrang, dan Masyarakat. Selain dari itu penulis akan membahas tentang implementasi kebijakan pengadaan beras BULOG dalam mewujudkan ketahanan pangan di Kabupaten Pinrang.

Dalam pencapaian target dan realisasi pengadaan beras dalam negeri, terlihat dari tiga tahun terakhir yaitu tahun 2018-2020, bahwa Perum Bulog Cabang Pembantu Pinrang belum maksimal memenuhi dan mencapai target yang sudah ditentukan. Hal ini sesuai berdasarkan data yang didapatkan oleh peneliti sebagai berikut:

Tabel Daftar Target Dan Realisasi Pengadaan Beras Bulog Tahun 2018-2020 Perum BULOG Cabang Pembantu Pinrang

\begin{tabular}{ccccc}
\hline \multirow{2}{*}{ No } & \multirow{2}{*}{ Uraian } & \multicolumn{3}{c}{ Tahun (Ton) } \\
\cline { 3 - 5 } & & $\mathbf{2 0 1 8}$ & $\mathbf{2 0 1 9}$ & $\mathbf{2 0 2 0}$ \\
\hline 1. & Target & 32.081 & 36.406 & 56.780 \\
\hline 2. & Realisasi & 29.279 & 34.916 & 55.080 \\
\hline & \% Pencapaian & 91,2 & 95,9 & 97,0 \\
\hline
\end{tabular}

Sumber: BULOG KCP Pinrang 2021

Dilihat dari tabel diatas dapat disimpulkan bahwa pengadaan beras bulog dari tahun 2018-2020 belum mencapai target yang telah ditentukan karena adanya beberapa faktor yaitu;

Dari penjelasan bapak M. Asri selaku pemilik KP Erwin menyatakan bahwa yang menjadi kendala kurangnya jumlah stok pemasukan beras ke BULOG adalah rendahnya harga pembelian pemerintah terhadap beras sedangkan harga yang dipasaran berbeda dengan harga yang ada di BULOG, sehingga kilang padi Erwin jarang menjual berasnya ke Bulog. Dan dipenggilingan padi milik bapak M. Asri belum bisa menghasilkan beras yang bagus atau premium. Juumlah pemasukan beras $\mathrm{kp}$ Erwin ke BULOG bisa mencapai 80-100 ton dalam masa kontrak kerja dengan bulog dan harus memenuhi standar atau persyaratan yang telah disepakati bersama dengan BULOG.
Senada dengan penjelasan Kepala Perum BULOG Cabang pembantu pinrang yang mengatakan bahwa faktor penghambat yang tidak dapat dihindari adalah faktor alam, pergantian cuaca yang tidak menentu menyebabkan bencana alam seperti banjir dan kekeringan sehingga petani gagal panen, belum lagi permasalahan serangan hama dan penyakit tanaman lainnya. Kegagalan panen menjadi salah satu penghambat beras yang berimbas pada jumlah realisasi pengadaan beras yang menurun dan target pengadaanpun tidak terpenuhi. Sedangkan yang menjadi faktor lainnya yaitu beberapa pengusaha kilang padi merasa dilema antara menjual berasnya ke BULOG dengan harga pembelian yang rendah.

Dalam pelaksanaan pengadaan beras dilapangan, Perum BULOG melibatkan dua pihak untuk mendukung ngadaan beras yaitu Satuan Kerja Pengadaan (Satker ADA DN) yang dibentuk oleh masing-masing kasubdrive 
jadi anggotanya merupakan karyawan oganik dilingkungan Perum BULOG baik yang sudah karyawan tetap maupun calon karyawan. Dan pihak kedua adalah Mitra Kerja Pengadaan (MKP) yang terdiri dari perusahaan yang berbadan hukum, badan usaha, BUMDes atau usaha perseorangan, Kelompok Tani/Gabungan Kelompok Tani (Poktan/Gapoktan) dan lumbung pangan desa yang memenuhi persyaratan untuk melakukan kerjasama pengadaan.

\section{Komunikasi}

Komunikasi adalah hal sangat penting dalam mengimplementasikan suatu kebijakan karena komunikasi merupakan penentu untuk berhasil tidaknya suatu kebijakan tersebut. Adanya komunikasi yang baik antara pemerintah dan masyarakat, maka dalam mengimplementasikan suatu kebijakan dapat dipastikan berjalan dengan baik dan lancar. Sesuai dengan pengamatan penulis dan observasi dilapangan serta wawancara langsung, maka salah satu bentuk komunikasi dalam implementasi kebijakan pengadaan beras BULOG dalam mewujudkan ketahanan pangan di Kabupaten Pinrang. Salah satu yang dilakukan oleh Perum BULOG Cabang Pembantu Pinrang yaitu melakukan kerjasama dengan instansi lain seperti dinas ketahanan pangan, mitra kerja dan pedagang pengecer.

Hubungan komunikasi antara instansi terkait dengan mitra kerja terjadi pada saat BULOG melakukan seleksi terhadap mitra kerja yang akan menjual berasnya ke BULOG kemudian berkoordinasi dengan seksi pengadaan, pelayanan publik, dan analisa \& pasar tentang standar kualitas beras serta harga beli beras. Dan BULOG sudah melakukan komunikasi terhadap mitra kerja dengan baik dengan mendatangi mitra kerja untuk mensosialisasikan harga beli beras.

Berdasarkan hasil pengamatan yang dilakukan oleh peneliti mengenai hubungan komunikasi antar BULOG dengan para implementor lainnya sudah berjalan dengan baik. Dinas ketahanan pangan juga sudah menjalankan perannya sebagai instansi yang membantu BULOG untuk menjalankan kebijakan pengadaan beras melalui dengan memberikan data yang dibutuhkan oleh BULOG dan melakukan sosialisasi kepada masyarakat untuk menjual berasnya ke
BULOG dengan harga beli yang sudah ditetapkan oleh pemerintah.

Satuan kerja Perum BULOG Cabang Pembantu Pinrang melakukan penyaluran bansos sesuai dengan instruksi pemerintah yang disalurkan ditiap-tiap kecamatan. Dan setelah diterima oleh pihak kecamatan, maka pihak kecamatan yang akan memberikan kepada masyarakat. Untuk memaksimalkan kinerja dalam suatu keberhasilan, maka perlu adanya kesesuian terhadap pembagian tugas dan fungsi sebagai pembuat kebijakan. Dalam pembentukan fungsi Perum BULOG, pembagian fungsi sudah ditentukan oleh pemerintah pusat. Untuk pengadaan beras, seksi yang berperan dan bertanggung jawab adalah seksi pengadaan, pelayanan publik, dan analisa pasar inilah yang melakukan seleksi beras dan sosialisasi harga beli beras terhadap pengusaha kilang padi.

\section{Sumber Daya}

Berhasilnya suatu implementasi kebijakan tidak hanya dilihat dari segi komunikasi akan tetapi dilihat juga dari segi sumber daya manusia. Dalam implementasi suatu program atau kebijakan sumber daya manusia sangat diperlukan karena dengan adanya sumber daya manusia yang mendukung, maka implementasi kebijakan dapat dikatakan efektif.

Adapun yang menjadi sumber daya manusia yang terlibat dalam pengadaan beras BULOG untuk mewujudkan ketahanan pangan di Kabupaten Pinrang yaitu semua pihak yang ada didalam internal Perum BULOG itu sendiri. Pihak internal dan pihak eksternal yang terlibat dalam pengadaan beras BULOG yaitu mitra kerja, dinas ketahanan pangan, dan tim satker pengadaan.

Selain faktor sumber daya manusia dalam melaksanakan implementasi kebijakan yaitu terdapat faktor sumber daya finansial karena besarnya dukungan alokasi dana akan mempengaruhi bagaimana kinerja penerapan implementasi tersebut. Adapun sumber daya finansial pengadaan beras BULOG untuk mewujudkan ketahanan pangan di Kabupaten Pinrang berasal dari anggaran yang dikeluarkan dari kantor pusat yang berasal dari kredit komersil BULOG.

Dalam menjaga kestabilan pelaksanaan implementasi kebijakan berlangsung selain membutuhkan komitmen dari sumber daya 
manusia dan dukungan dari sumber daya finansial juga dibutuhkan kualitas sumber daya fasilitas dalam bentuk sarana dan prasarana dalam membantu kinerja organisasi. Peralatan yang terdapat dilingkungan Perum BULOG Cabang Pembantu Pinrang dinilai cukup memadai untuk mendukung pelaksanaan kebijakan BULOG dan masih bisa digunakan. Namun, selain dari pihak Perum BULOG dan pihak Dinas Ketahanan Pangan Kabupaten Pinrang, sumber daya fasilitas juga dirasakan oleh pihak pengusaha kilang padi. Para pengusaha kilang padi mengeluhkan persoalan fasilitas mesin penggilingan padi yang tidak seimbang dengan jumlah hasil panen padi petani. Dan mesin penggilingan padi yang mereka miliki belum kompoten menghasilkan beras yang kualitas terbaik atau premium, sehingga terjadinya impor beras karena kurangnya permintaan masyarakat terhadap beras BULOG.

\section{Disposisi}

Implementasi kebijakan tidak hanya diukur dari dua indikator saja yaitu komunikasi dan sumber daya. Akan tetapi harus juga di ukur dari segi disposisi atau sikap implementor. Berdasarkan hasil pengamatan yang dilakukan oleh peneliti terkait sikap karakteristik dan kemampuan yang dimiliki oleh Perum BULOG Cabang Pembantu Pinrang belum sesuai dikarenakan kurangnya pegawai di instansi tersebut sehingga belum maksimal dalam mengontrol dan mengkoordinasi setiap kegiatan dalam pengadaan beras BULOG untuk mewujudkan ketahanan pangan di Kabupaten Pinrang. Meskipun sumber daya yang masih kurang memadai, tetapi para implementor tetap bertanggung jawab dalam menjalankan tugasnya sebagai pelaksana kebijakan.

Dalam kegiataan pengadaan beras, Perum BULOG melakukan pendidikan dan pelatihan khusus untuk meningkatkan keterampilan teknis dan manajerial dalam pengadaan beras yang dilakukan oleh Perum BULOG. Tujuan dilakukan pelatihan ini adalah agar para pegawai melakukan proses pembelajaran sehingga para pegawai memiliki keahlian serta konsep yang dapat mengembangkan produktivitas kerja dan kompetensi.

Sikap karakteristik yang dimiliki oleh BULOG Cabang Pembantu Pinrang yaitu mengacu kepada aturan yang ada, apabila para pengusaha kilang padi ingin menjual berasnya ke BULOG, mereka harus penuhi aturan yang sudah ditetapkan oleh Pemerintah Pusat. Apabila tidak sesuai dengan aturan yang diberikan oleh BULOG maka beras tersebut akan dikembalikan kepada para pengusaha kilang padi untuk segera diperbaiki. Tetapi dalam pelaksaan ini masih aman, dan sudah memenuhi syarat untuk menjual berasnya kepada BULOG.

\section{Struktur Birokrasi}

Dalam implementasi kebijakan tidaklah lengkap apabila tidak ada struktur birokrasi di dalamnya. Struktur birokrasi merupakan karakteristik, norma-norma pola-pola hubungan yang terjadi secara berulang-ulang. Salah satu aspek struktur birokrasi adalah adanya prosedur operasi yang standar atau SOP yang berfungsi menjadi pedoman bagi setiap implementor dalam bertindak. dalam melakukan kebijakan pengadaan beras, BULOG Cabang Pembantu Pinrang melaksanakan kebijakan tersebut sesuai dengan standar operasional prosedur atau sesuai dengan petunjuk dari pemerintah pusat.

Berdasarkan observasi yang dilakukan oleh peneliti mengenai struktur birokrasi Perum BULOG Cabang Pembantu Pinrang dalam menjalankan kebijakan pengadaan beras BULOG terlihat bahwa adanya struktur pembagian tugas pokok dan fungsi yang dijalankan pegawai terkait pengadaan beras. Seksi pengadaan, pelayanan publik dan analisa \& pasar merupakan seksi yang akan menangani pengadaan beras BULOG, akan tetapi semua bidang dan kepala BULOG Cabang Pembantu Pinrang ikut serta dan bertanggung jawab dalam pelaksanaan kebijakan pengadaan beras ini.

Dalam menjalankan kebijakan tersebut, BULOG hanya menjalankan sesuai dengan tupoksi pada masing-masing bidang terkait kebijakan tersebut. Karena semua bidang hanya berfokus untuk menjalankan program itu. Dalam pembagian kebijakan yang akan ditetapkan oleh pemerintah pusat, BULOG Cabang Pembantu Pinrang hanya sebagai operasionalisasi kebijakan yang telah ditetapkan. dalam proses penentuan kebijakan di BULOG Cabang Pembantu Pinrang sudah sesuai dengan prosedur yang ada karena 
ditentukan langsung oleh Kepala Perum BULOG. Tetapi dalam operasional dan teknisnya di lapangan melibatkan pihak-pihak yang terkait seperti bagian pengadaan dan keuangan.

Pada struktur birokrasi yang dilakukan oleh Perum BULOG terdapat dua mekanisme yaitu melalui mitra pengadaan misalnya dari para pengusaha kilang padi dan dari perorangan yang mempunyai usaha. Dan melalui SATKAS dalam artian pihak internal BULOG turun langsung ke lapangan penggilingan, yang tidak masuk dalam mitra kerjasama BULOG, maka BULOG memberi dorongan kepada para pengusaha kilang padi untuk bekerjasama dengan Perum BULOG.

\section{KESIMPULAN}

Berdasarkan dari hasil penelitian penulis terkait dengan judul yang diangkat, dapat disimpulkan bahwa Implementasi Kebijakan Pengadaan Beras Badan Urusan Logistik Dalam Mewujudkan Ketahanan Pangan Di Kabupaten Pinrang belum maksimal sesuai dengan empat (4) indikator dari Teori Edwar III yaitu; (a) Komunikasi. Berjalannya suatu Implementasi kebijakan pengadaan beras di Kabupaten Pinrang salah satu bentuk komunikasi yang dilakukan oleh Perum BULOG Cabang Pembantu Pinrang yaitu melakukan kerjasama dengan dinas ketahanan pangan dan mitra kerja pengusaha kilang padi untuk mensosialisasikan harga beli beras BULOG. (b) Sumber Daya, dalam hal ini sumber daya masih kurang memadai termasuk sumber daya manusia, dan sumber daya lainnya yaitu fasilitas masih kurangnya alatalat mesin yang bisa menghasilkan beras premium. (c) Disposisi, kemampuan Perum BULOG Cabang Pembantu Pinrang belum maksimal dalam mengotrol dan mengkoordiasi kegiataan pengadaan beras BULOG, sehingga Perum BULOG melakukan pendidikan dan pelatihan khusus untuk meningkatkan keterampilan teknis dan manajerial dalam pengadaan beras yang dilakukan oleh BULOG. (d) Struktur Birokrasi. Perum BULOG Cabang Pembantu Pinrang dalam menjalankan kebijakan tersebut sesuai dengan tugas pokok dan fungsi pada masing-masing bidang yang terkait tetapi semua pihak bertanggung jawab dalam pelaksanaan pengadaan beras BULOG tersebut.

\section{REFERENSI}

Lutfi Alifia, 2001, Implementasi Program Peningkatan Ketahanan Pangan (Studi pada Dinas Pertanian Kabupaten Blitar), Jurnal Ilmiah Adminnistrasi Publik, Volume 2 No 3 Tahun 2011.

Langkai, Jeane Elisabeth. (2020). Kebijakan Publik. Malang-Jawa Timur Indonesia; CV. Seribu Bintang.

Nuraini (2013). Meningkatkan Ketahanan Pangan dalam masyarakat (studi:sinergi kelembagaan dalam implementasi kebijakan pengadaan beras di Kab Banyumas). Sawala jurnal administrasi negara, ii, (2), hlm 11-18.

Purwanto E.A Sulistyastuti D.R, 2002, Implementasi Kebijakan Publik, Konsep dan Implementasinya di Indonesia, Gava Media, Yogyakarta.

Suaib Muhammad Ridha. 2016. Pengantar Kebijakan Publik : Dari Administrasi Negara, Kebijakan Publik, Pelayanan Publik, Good Governance Hingga Implementasi Kebijakan, Yogyakarta: Candi Kebang.

Suharsono, A.G, 2005. Analisis Kebijakan Publik, Konsep, Teori dan Aplikasinya. Pustaka pelajar. Yogyakarta.

Pemerintah Republik Indonesia. (2012). Undang-Undang Republik Indonesia Nomor 18 Tahun 2012 tentang Pangan. Jakarta: Pemerintah Republik Indonesia.

Perum BULOG : BULOG dalam Pilar Ketahanan Pangan (http:www.bulog.co.id/ketahananpang an.php.acses.02/02/2020) 
Parawangi, Anwar. 2011. Implementasi Program Nasional Pemberdayaan Masyarakat (Studi Kasus Pengembangan Infrastruktur Sosial Ekonomi Wilayah Di Kabupaten Bone). Disertasi, Program Pasca Sarjana Universitas Muhammadiyah Makassar.

Nugroho, Riant. 2020. Model-Model Perumusan Kebijakan Publik. Jakarta Selatan: Yayasan Rumah Reformasi Kebijakan.

Mustari Nuryanti. (2015). Pemahaman Kebijakan Publik Formulasi, Implementasi dan Evaluasi Kebijakan Publik. Yogyakarta: LeotikaPrio. 